\title{
Turkey's EU accession as a question of nation brand image
}

Received (in revised form): 29th November, 2006

\section{Jan Dirk Kemming}

works as Creative Planner for Weber Shandwick in Germany. He recently finished his MSc in Marketing at Bilkent University, Turkey, and is currently engaged with his PhD dissertation on Turkey's nation brand image in political contexts.

\section{Özlem Sandikci}

is an assistant professor at the Faculty of Business Administration at Bilkent University, Turkey. She has a PhD in Marketing from the Pennsylvania State University. Her research interest lies in the areas of consumption and globalisation.

Abstract Despite the significance of politics and public diplomacy for nation brands, there is little research on the topic. The study seeks to contribute to the literature by investigating Turkey's European Union (EU) accession, which seems endangered by negative public opinion in other EU member states, as a case to understand how nation brand images can influence a given course of action in international politics. Specifically, through an exploratory qualitative research, the content of Turkey's nation brand image, its antecedents, and potential consequences within the political context of the country's accession negotiation are explored. The findings suggest that Turkey, at the moment, does not appear to be a well-run nation brand. Not only do the poor results indicate room for improvement, but also the management of Turkey in all relevant nation brand dimensions does not seem promising with regard to a successful EU application process. Furthermore, the analysis point to a truly complicated positioning dilemma for Turkey's nation brand and the challenge of accomplishing an integrated nation brand management. The paper concludes by outlining policy and research implications.

Place Branding and Public Diplomacy (2007) 3, 31-41. doi:10.1057/palgrave.pb.6000046

Keywords: Place branding, nation brand, public diplomacy, Turkey, European Union

\section{INTRODUCTION}

Much of the literature on nation branding has focused on one of the three dominant research areas: the country-of-origin (COO) effects for export products (eg Jaffe and Nebenzahl, 2001; Jaworski and Fosher, 2003), branding tourist destinations (eg Baloglu and McCleary, 1999; Fesenmaier and MacKay, 1996), and acquiring foreign investments (eg Pantzalis and Rodrigues, 1999; Papadopoulos and Heslop, 2002). However, 'there is far more to a powerful nation brand image than simply boosting branded exports around the world' (Anholt, 2002: 44) and 'it is essential for countries to understand how they are seen by publics around the world; how their achievements and failures, their assets and liabilities, their people and their products are reflected in their brand image' (Anholt and GMI, 2005a: 1). Reputation management and influencing public opinion in other countries have become important drivers of foreign politics, and public diplomacy now plays an important role in communicating a nation's policies and culture to international audiences (Anholt and 
Hildreth, 2005). Despite the significance of politics and public diplomacy for effective management of nation brands, there is, however, little research on the topic (Anholt, 2002; Kyriacou and Cromwell, 2005a, 2005b; Vaknin, 2005; Wang 2006). The study seeks to contribute to the literature by investigating Turkey's European Union (EU) accession as a case to understand how nation brand images can influence the course of action in international politics. Specifically, through an exploratory qualitative research study, we explore the nation brand image of Turkey and its antecedents and consequences within the political context of EU accession.

Turkey has a long and troubled history with the EU. As early as 1959, Turkey applied for membership in the European Economic Community (EEC). In 1963, the contractual framework known as the Ankara Agreement, which outlined the accession perspective of Turkey, was signed. Finally, in December 2004, the EU heads of state declared Turkey's fulfilment of the Copenhagen criteria, ${ }^{1}$ and a first realistic accession scenario was provided by opening the negotiations about the EU's aquis communitaire $^{2}$ in October 2005. Notwithstanding this clear utterance of political will, the process is not fully in Turkey's and EU governments' hands. As Kalaycioğlu (2005: 1) points out, 'there will be exogenous variables, which are factors that cannot be controlled, for example, the votes of people who take an ideological approach to the issue. No matter how well Turkey does, this may not eliminate enmity toward Turks.' In other words, 'in the next 10 or 15 years..., when all is set for membership what may matter most is the European public opinion against Turkey' (Briefing, 2005: 8).

The paper begins by discussing Turkey's nation brand and the public opinion over Turkey's EU membership bid as reflected in the Eurobarometer public opinion polls (European Commission, 2006). Next, the research goals are provided and the methodology of the study is outlined. The findings are organised into three categories: distribution of Turkey's nation brand image across EU-Europe, factors influencing
Turkey's nation brand image, and consequences resulting from Turkey's nation brand image. The paper concludes by discussing policy and research implications.

\section{TURKEY'S NATION BRAND AND OPINIONS OVER ITS EU MEMBERSHIP BID}

In 1923, during the foundation of the modern Turkish Republic, nation branding efforts were tremendous:

'Ataturk's branding operations in the defeated Ottoman Empire after the First World War rivalled those of the first French Revolution in scope and scale; they involved a new alphabet, new clothing (all men had to wear smart Western headgear or at least a Turkish version of it), ethnic cleansing, a new name for the nation and new names for all inhabitants, and perhaps most importantly in view of recent developments, a secular rather than a religious state' (Olins, 2002: 245).

Despite all efforts, today Turkey's nation brand status seems quite marginal. In fact, in all Anholt/GMI's Nation Brand Index reports published so far, Turkey has never managed to leave the last rank of the list. Perceptions of Turkey by the citizens of European countries are dramatically low, which is why Anholt and GMI (2005b: 19) concludes: 'It is a concern that, despite Turkey now having started EU accession talks, ordinary consumers in several of its future European partner states put it bottom overall, including Spain, France, Germany, Denmark and Italy'.

A number of surveys indicate a substantial opposition among many of the current member states toward Turkey joining the EU (eg European Commission, 2006; Transatlantic Trends, 2005). A closer look at the public opinion surveys evokes some interesting questions. The results of the Eurobarometer (semiannual polls ordered by the European Commission measuring the public opinion on different issues across all 25 member states) repeatedly show that public opinion toward Turkey's EU membership ranges from strict opposition to rather favourable positions. The 
Table 1: Public opinion on Turkey's EU membership (adapted from European Commission, 2006)

\begin{tabular}{lll}
\hline Rather in favour & Mixed opinion & Rather against \\
\hline - Poland & - Hungary & - France \\
- Spain & - Malta & - Netherlands \\
- Sweden & - UK & - Belgium \\
- Slovenia & - Portugal & - Dermany \\
& & - Ireland \\
& - Austria \\
& - Czech Republic \\
& - Italy \\
& - Greece \\
& - Estonia \\
& - Republic of \\
& & Cyprus \\
& & - Latvia \\
& & - Lithuania \\
& & - Suxembourg \\
& & - Finland \\
& &
\end{tabular}

following table, adapted from Eurobarometer 2005 fall data, summarises the tendencies in the individual EU nations on Turkey's EU membership (Table 1). ${ }^{3}$

In only a few countries, the public holds Turkey's EU bid in favourable regard; in the majority, public opinion is clearly not in favour. However, while it is possible to provide speculative explanations for the position of certain countries, the overall distribution of the public opinion about Turkey across Europe seems difficult to explain at first sight. For example:

- In the light of the repeatedly raised 'EU is a Christian club' argument, the strong Christian orientation of Spain should therefore potentially contradict a strong backing for Turkey; whereas, Spain is rather in favour, and a fairly secular country like the Czech Republic is rather against Turkey's membership.

- While Austria, Hungary and Slovenia probably share similar historical experiences with the Turkish/Ottoman occupation, in Austria Turkish membership is regarded much more critically than in Hungary; Slovenes, on the other hand, are in the majority actually welcoming Turkey's membership.
- A large Muslim immigration history might explain why Turkey's membership request would be rejected in France; however, this would be contravened by the British position toward Turkey.

- Finally, there is no consistent pattern in the data that indicates acts of solidarity toward Turkey from Mediterranean countries like Spain, Italy and Greece, for example, or from newly joined member states like Poland or Slovakia.

The diverse public opinion suggests that a unified European public characterised by a consensually developed informed opinion with regard to Turkey is not in immediate sight (Giannakopoulos and Maras, 2005). Furthermore, it is expected that the apparent rift between governmental policies and public opinion could actually deepen during the course of negotiations (Independent Commission, 2004: 29). Clearly, the European disfavour will not only affect the negotiation process but also the very important reform process in Turkey and the development of a European identity among Turks themselves. The current situation appears to be approaching a deadlock as Olli Rehn, EU enlargement commissioner and a champion of opening the talks, explains: "We have a vicious circle at the moment, so that negative public opinion in Europe has an impact on political leaders, [...] that in turn erodes the credibility of the accession perspective in the eyes of the Turks and has a negative impact on the reform process' (quoted in Dombey, 2005: 8). Overall, it appears that negative public opinion on Turkey's EU accession in many member states might become a major obstacle during the negotiations despite supportive diplomatic interactions.

\section{THE RESEARCH}

From a marketing perspective, the results of the public opinion surveys indicate that Turkey has an image problem among its target audiences. As Anholt and GMI (2005b: 19) also argue, Turkey 'has a very weak international brand 
image, and brand image plays a more fundamental role in questions of international relations and regional integration than many people imagine'. Following Omura and Talarzyk's (1985: 95) suggestion that 'the application of consumer behaviour theories in the political arena can increase understanding of the dynamics of public opinion,' this study explores Turkey's EU accession from the perspective of nation brand image theory.

Image can be considered as the meaning system that we attach to a phenomenon. Nation brand image, in particular, 'expresses personalised feelings of what people know and think about a country, and it is developed by representative products, national characteristics, economic and political background, history, tradition etc' (Ger, 1991: 391). Marketing literature on the image construct suggests that the investigation of a nation's brand image should go beyond the analysis of isolated image dimensions to a holistic approach that explores both the factors influential in the formation of the image and the consequences of the image including various forms of political behaviour. Thus, this study examines Turkey's nation brand image with its underlying factors and resultant consequences within the political context of EU accession.

Given the scarcity of research that applies nation brand image theory to political contexts, the current study is exploratory in nature and seeks to provide only a conceptual framework that may generate further research on the topic. The nature and goal of the study suggested that applying qualitative research methods, which enable researchers to gain an in-depth understanding of the phenomenon at hand, was the most appropriate methodological approach. Data were collected through semi-structured in-depth interviews conducted with a total of 34 informants between June 2005 and January 2006 in Turkey and some EU member states.

The selection of the sample took place in two stages. First, a sample of member states was determined. Next, informants from each of the states selected for the sample were identified. A purposeful sample of six out of all 25 current member states was drawn to account for typical political, structural and cultural characteristics. The selection criteria included size, ${ }^{4}$ wealth, ${ }^{5}$ EURO-acceptance, ${ }^{6}$ geographical region, ${ }^{7}$ main religious orientation, ${ }^{8}$ duration of the nation's EU membership, ${ }^{9}$ share of Turkish migrants in the population, ${ }^{10}$ and trade ${ }^{11}$ - and tourism ${ }^{12}$ involvement with Turkey. The countries chosen were The Netherlands, Germany, the UK, Spain, Sweden and Slovenia. Turkey was added to that sample to compare inside and outside perspectives. Table 2 summarises the sample of countries along the selection criteria.

At the second stage, experts from different fields such as politics, marketing or media, were selected as sources of information. The informants included EU ambassadors and embassy staff located in Ankara, European politicians with specific knowledge of Turkey, European media correspondents in Turkey, political consultants both in Turkey and EU countries, and EU-European expatriates settled in Turkey. The informants were identified and recruited through both systematic inquiry and snowball sampling techniques during the field research conducted in Turkey and in some

Table 2: Sampling of EU countries

\begin{tabular}{|c|c|c|c|c|c|c|c|c|c|}
\hline Country & Size & Wealth & Euro & Region & $\begin{array}{l}\text { EU } \\
\text { membership }\end{array}$ & Religion & $\begin{array}{l}\text { Turkish } \\
\text { population }\end{array}$ & Trade TR & $\begin{array}{l}\text { Tourism to } \\
\text { TR }\end{array}$ \\
\hline Netherlands & Small & Rich & Yes & Central & Old & Mixed & Large & Middle & Middle \\
\hline Germany & Large & Rich & Yes & Central & Old & Mixed & Large & High & High \\
\hline Spain & Large & Poor & Yes & South & Medium & Cath. & Small & Middle & Low \\
\hline Sweden & Small & Rich & No & North & Medium & Prot. & Small & Low & Middle \\
\hline Slovenia & Small & Poor & No & South & New & Cath. & Small & Low & Low \\
\hline
\end{tabular}


EU-member states. All the interviews followed a common topic guideline and were digitally recorded and transcribed. The interviews were between 20 and $90 \mathrm{~min}$ in duration.

Data analysis involved development of codes and categories. During the open coding phase, the main themes emerging from the data were identified and labelled; next, axial coding was employed to organise the connections of the main themes and with the concepts in the literature (Coffey and Atkinson, 1996). The codes for every transcribed interview were sorted into one of the 15 categories that were suggested by the data and the literature. Some of these categories were: general image content seen by the informant; stereotypical characteristics of Turkey; tourism image; export products 'Made in Turkey'/FDI; political image; remarks about referenda/voting scenario; positioning Turkey's nation brand; and tactics/ communicative actions to be taken by Turkey. The information gathered for each category from the informants of each country was summarised in a short trend statement. These trend statements were compared country by country, continuously going back to the dataset to confirm meaningful differences or similarities.

Authenticity and topic involvement of expert informants served as a criterion of reliability. Triangulation across different domains like social, political, economic and media accounted for trustworthiness of the research in terms of credibility. Engaging with the issue in its broader context (media observation both in Turkey and in some EU-countries provided supplemental datasets) for more than two years additionally contributed to the integrity of the information (Wallendorf and Belk, 1989). The announcement to open EU accession talks with Turkey in 17th December, 2004 and the confirmation on 3rd October, 2005 served as essential conditions and cornerstones for the internal validity; they and the expected longterm horizon of 10-15 years of negotiation period ensured stable political contexts at least with respect to strategic issues for the time of the research project and potential biases due to topicalities.

\section{FINDINGS}

As the following summary of the findings shows, Turkey's image is quite vibrant across EU-Europe, and there are many factors underlying such a diverse image as well as its possible consequences for Turkey's EU accession process.

\section{Distribution of Turkey's nation brand image across EU-Europe}

The content of Turkey's nation brand image was generated in two ways: On the one hand, with the help of projective techniques, overall perceptions of Turkey in the chosen EU countries were elicited. On the other hand, particular nation brand dimensions like tourism image, economic aspects (ie export products or investment opportunities), role of politics, and finally people- and culture-related factors were examined in more detail. Table 3 summarises the results:

The general image of Turkey seems quite good in the UK and Spain, where the positive aspects of Turkey's EU bid clearly outweigh the perceived negative ones. A mixed picture was found for Sweden and Slovenia. There are clearly more negative issues than were observed in Spain or UK, yet it could not be claimed that these would be decisive for a rejection of Turkey; the perceptions seem balanced. A clearly negative public image of Turkey was observed in The Netherlands and Germany.

Interesting contrasts were depicted between the Turkish self-image and the images held by the foreign experts. While foreigners often painted the picture of a quite attractive but unreliable nation, which expresses a common overestimation, the Turkish image/selfperception involved complaint rather than underestimation: by Turks, the nation was perceived to be reliable and hard-working, but its potential was believed to be unrecognised by the outside world.

\section{Factors influencing Turkey's nation brand image}

The analysis of data indicated the following possible reasons or motives underlying the 
Table 3: Summaries of Turkey's nation brand image dimensions in the sampled countries (NL=The Netherlands, GER=Germany, UK=United Kingdom, ESP=Spain, SWE=Sweden, SLOV=Slovenia, TR=Turkey)

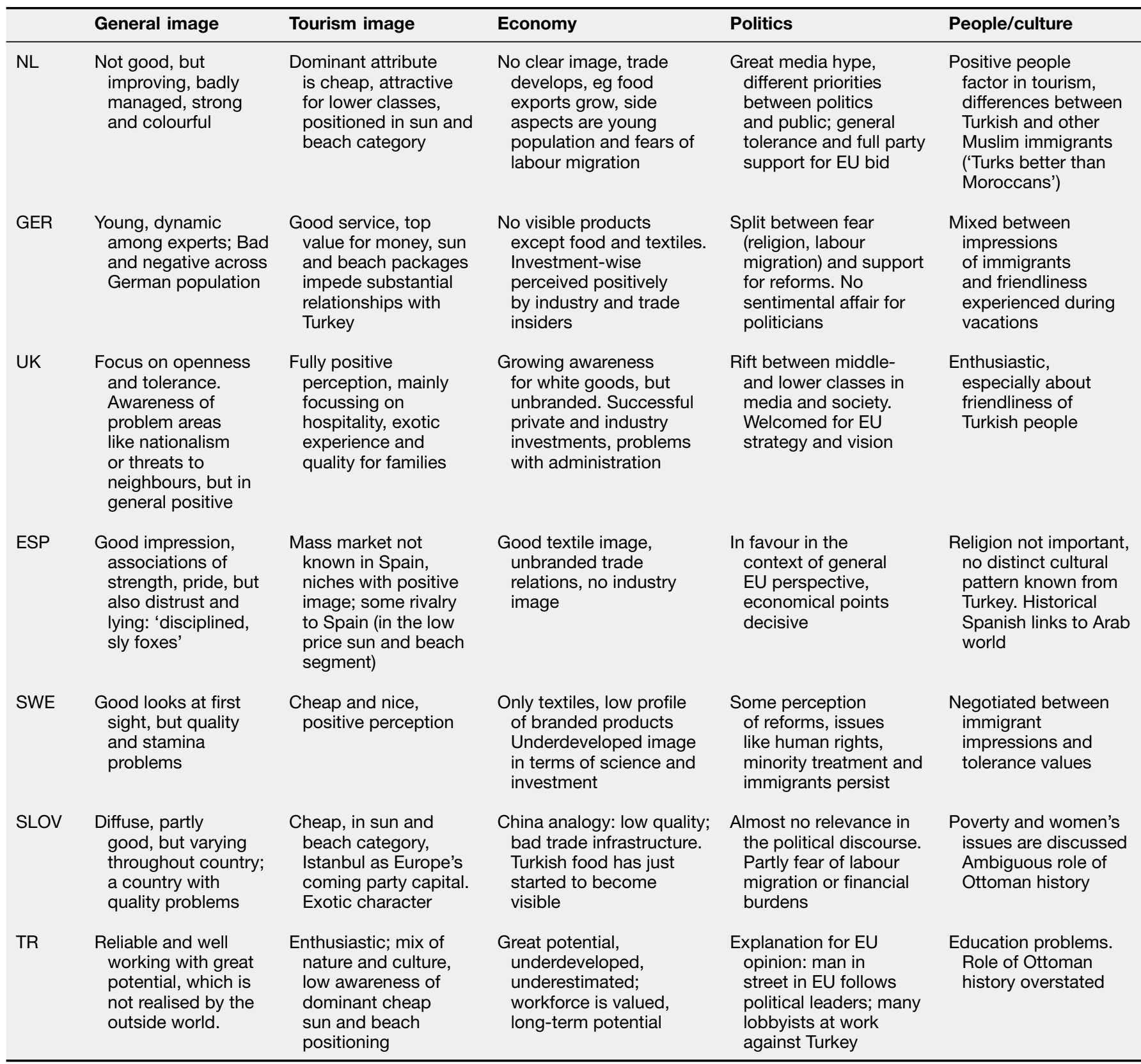

distribution of Turkey's nation brand image across the EU:

- Significant differences in Turkey's perception largely depend on the brand dimension 'people'. Other classical nation brand dimensions such as tourism or export-products seem to have a comparably minor influence. The varying degrees of success integrating Turkish and Muslim immigrants into EU countries like The Netherlands, UK or Germany are a very important explanation for Turkey's image. 
- A nation's positioning within the EU will determine the perception of Turkey's EU accession: Elder and established member states tend to see and discuss Turkey more negatively than more recent additions. The polarised visions of the EU (intergovernmentalist versus federalist) also seem to influence the evaluations.

- Stereotypes and cultural practises related to Turks and Turkey were found to shape the image. In almost every nation in the sample, typical collocations, proverbs or rituals related to Turkey or Turks were found. For example, the phrase 'Mamma mia, the Turks are coming' in Italian, or the children song ' $\mathrm{C}-\mathrm{A}-\mathrm{F}-\mathrm{F}-\mathrm{E}$ ' in Germany warning children not to drink too much coffee since the Turk's drink is not good for them. Awareness of these might not necessarily explain individual dispositions toward Turkey, but indicate the cultural context of the stereotypes.

- Trade involvement with Turkey cannot qualify as a factor of nation brand image at the moment. Export products are largely unfamiliar to EU-Europe's citizens. The emerging or stabilising Turkish economy and resulting investment opportunities seem to mostly take place in insider discourses, but have not reached the broader public as an image facet of Turkey.

- Religion, often mentioned in the context of Turkey's EU membership, seems not to be a major influence for Turkey's nation brand image. Religious discourses might serve as a metaphor for general culture in order to qualify unknown or strange behaviours. The extent of religious practise (how visible religion is to the public eye) seems to be a more relevant factor than Turkey simply being a Muslim country. One expert stated: 'So the difference is not only being Muslim versus Christian, but a very religious [...] country vis-à-vis a post-religious continent.'

- Knowledge structures like those stemming from tourism experiences can positively influence an image if they do not collide with other dimensions of a nation brand that might be even more persistent and present. Both for The Netherlands and Germany, generally positive tourism experiences are not able to substantially contribute to Turkey's image in the political context. It seems as if for people of those nations new impressions cannot get through the dense layer of existing stereotypes. However, in the UK and Sweden, where no deeply rooted prejudices seem to exist, the tourism experience can contribute positively to the overall image.

- Proximity and familiarity lead to a mixed picture: In both Spain and the UK, even after the bombings in London in 2005 and Madrid in 2004, no generally negative discourses about the Muslim and/or Arab world, which would influence the perception of Turkey, were reported. Germany and Netherlands, however, are in close negative contact with Turkish immigrants, which leads to a quite negative position toward Turkey. Slovenia has no contact, which leads to a rather indifferent position. Accordingly, a factor like familiarity, and the type of contact, will need to be carefully analysed for the case of Turkey's EU accession.

- Involvement, which is regarded as an umbrella construct for familiarity, knowledge and interactions with a product within marketing theory does not seem to provide a clear explanation. Spain and Slovenia appear to be societies that have little involvement with issues relating to Turkey. In one case (Spain) the image turns out to be quite positive, in the other case (Slovenia) it is average. In the sample, UK and Sweden stand for average involvement cases. In both countries, although due to different reasons, the issue of Turkey's EU accession is not a high priority, yet ties to Turkey are quite visible. Despite these structural similarities, a positive image was found in the UK, but only an average overall nation brand image of Turkey emerged in Sweden. Finally, Germany and The Netherlands, seem to represent 
countries that are highly involved with Turkey, and in both cases, Turkey's nation brand image is rather negative.

- Turkey's current rather unidirectional and top-down executed communication activities in the areas of tourism and FDI-promotion, carried out mostly by traditional advertising channels, seem not to substantially contribute to a positive perception abroad and seem out of line with modern Turkish nation brand image content. Promising potential was detected for stronger 'people-to-people'-directed and more democratic communication activities between Turkey and the EU member-states, as intended within the EU civil society dialogue programmes.

\section{Consequences resulting from Turkey's nation brand image}

It is obvious that it is too early to prognosticate the role Turkey's nation brand image might play when it comes to public referenda in the member states on Turkey's EU accession. ${ }^{13}$ In addition, most experts from Europe do not consider the topic relevant enough for a permanent campaign or for discussion during regular domestic election situations in the EU countries. Yet the data reveals a possible concern that image aspects can and will seriously bias public discourses and voting behaviour in the coming 10-15 years of Turkey's accession negotiations with the EU.

The continuation of the reform process started in the past four years provides some reason for hope for improvement in the nation brand image of Turkey in the future. In line with other research findings, however, the results of this study also indicate how persistent brand imagedimensions and stereotypes remain over time:

\footnotetext{
'Turkey [...] suffers from an image which has been forged during an earlier and very different political era, and which now constantly obstructs its political, economic, cultural and social aspirations. In many ways, Turkey's brand image today in the West is in the same shape as if Ataturk had never lived' (Anholt, 2005: 3).
}

As Ger (1991) argues, images are knowledge structures which tend not to change too quickly. There is no doubt that Turkey should take some sustainable actions to work on its nation brand image. No government in EUEurope can, in the long run, rule against the majority will in the population. Turkey's image will need to undergo changes and a clearer picture of the nation brand will need to be perceived when the time comes to finally decide on Turkey's accession.

\section{IMPLICATIONS AND CONCLUSION}

The findings suggest that Turkey, at least for the moment, does not appear to have a well-run nation brand according to the experts that were interviewed. Not only do the poor results indicate room for improvement, but also the management of Turkey in all relevant nation brand dimensions does not seem promising with regard to a successful EU application process. Furthermore, the analysis point to a truly complicated positioning dilemma for Turkey's nation brand. Positioning alternatives oscillate between the poles of exoticism versus alikeness. The exotic aura of Turkey stemming in part from the mysterious Arabic/Middle Eastern associations contributes somewhat positively to tourism and, to a certain extent, its export products-driven image. For the political message of Turkey approximating EU-Europe, however, 'otherness' turns out to be one of the key problems. For political purposes, the message of alikeness with the European neighbours in terms of (industrial) standards, moral, ethics, sociality etc rather than difference would be absolutely necessary to emphasise. One considerable difficulty while showing alikeness is to find positive emotional ties, as alikeness messages tend to be rationalised and focus on tangible issues.

Furthermore, there is the challenge of accomplishing an integrative nation brand management. What used to be the essence of the Turkish Republic, that is the unity of Turkish identity, seems endangered nowadays. 
An intense dispute over the national identity secular versus religious, traditional versus modern, Western versus Eastern - does not only produce a confusing array of potential nation brand messages, but also leads to a presumably unmanageable mass of stakeholders. The role of the government in the nation brand management of Turkey, especially in terms of providing necessary funds, is critical. There is, however, scepticism about the government's competency in the development and execution of an effective nation brand management strategy. One possible solution to this problem is establishing a steering committee, consisting of experts from governmental and nongovernmental bodies, which would integrate political, technical and marketing competencies and execute the coordination and management of the nation brand. A related challenge in such a scenario would be the designation and the demarcation of roles and responsibilities. Coordination seems to be problematic not only in the public sector between governmental and non-governmental agencies, but also among the governmental institutions, such as ministries and information agencies, themselves.

A related issue is how to integrate a significant number of immigrants of Turkish descent residing all across Europe (eg approximately 3 million living in Germany, constituting almost 4 per cent of the German population) into the nation brand of Turkey and its management process. It appears to be necessary to relate inside and outside (= internal and external affairs) of Turkey's nation brand through, for example, cross-cultural dialogue programmes. Finally, the internal promotion of the EU within Turkey seems crucial for effective nation branding. Experiences from other EU accession processes of former candidate countries show how essential gaining the support of its own population will be. With significant scepticism toward EU membership among Turkey's public, ${ }^{14}$ the relevance of all Turks embracing the EU with enthusiasm is increasingly becoming a major challenge.

\section{Limitations and future research}

The qualitative nature of the study imposes certain limitations. As it is mostly the case in qualitative research, external validity of the study is limited; thus, the findings cannot be generalised to and across populations. Furthermore, given the sampling and data collection methods used, no numerical data and analysis can be reported. The judgmental sampling method used for the selection of both EU-countries and informants is commonly employed in qualitative research. Although studies based on judgmental sampling suffer from low external validity, this sampling method enables the researcher to select a few cases for intensive study and generate initial insights for follow-up studies.

Since this current study is exploratory in nature, overall, the reported findings indicate certain patterns and areas that require further research. Investigation of this problem in a subsequent quantitative study which will enable an analysis of the suggested correlations in the contextual nation brand image would be desirable both for academic and practical purposes. More detailed and substantive conclusions for actual foreign policy making and Turkey's public diplomacy strategy can be expected from studies conducted with a representative sample.

Building upon previously developed and (partly) validated quantitative models such as the Fombrun-RI country reputation index (CRI) by Passow et al. (2005) or Martin and Eroğlu's (1993) semantic differential scales for measuring national images seems quite promising in this regard. A notable number of experts during the interviews confirmed the lack of robust and reliable quantitative data on the perception of Turkey abroad. The contextual framework developed within this study should provide decent content and input to generate an innovative model containing independent and dependent variables of Turkey's nation brand image in the political context of the EU accession. 


\section{Notes}

1 Copenhagen Criteria are the political criteria set by the Copenhagen European Council in 1993, later enshrined in Article 6(1) of the Treaty on European Union and proclaimed in the Charter of Fundamental Rights, including stable democracy and human rights, rule of law, functioning market economy, application of the aquis communitaire and the Union's capacity to absorb new members (Briefing, 2005: 8).

2 The most important technicality of Turkey's EU accession is the assimilation of Turkey's national laws to the so-called acquis communitaire of the EU, which, organised in 35 chapters and containing more than 85,000 pages, represents the common set of rules, laws and directives of the community (Hagelueken, 2004: 2).

3 Answers to QA44: 'For each of the following countries, would you be in favour or against it becoming part of the European Union in the future? TURKEY'. Criteria: $>4$ per cent difference between approval and rejection: 'Rather in favour', between 4 and -4 per cent difference: 'Mixed' and $>-4 \%$ difference: 'Rather against'.

4 Measured in number of inhabitants, above $35 \mathrm{Mio}=$ 'large', below $35 \mathrm{Mio}=$ 'small', source: EUROSTAT.

5 In GDP per capita, according to the EUROSTAT index of EU $25=100(>100=$ 'rich' or $<100=$ 'poor').

6 Since no adequate means to comparably assess the 'intergovernmentalist vs federalist' distinction are available, EURO membership (which was mostly the result of referenda in the EU member states) was taken as rough indicator of the general EU perspective in the nations.

7 Differentiated in North (Scandinavia, Great Britain, Ireland and the Baltic States), Central (Continental Europe north of the Alps) and South (Mediterranean countries or countries with similar latitudes).

8 Indicated by more than 50 per cent of the population sharing one dominant religion, source: CIA factbook.

9 The six founding members of EU were referred to as 'old', successive accessions in enlargement rounds before opening to former East Block countries as 'middle', and 'new' refers to the ten member states entering in 2004.

10 Percentage of country's population with Turkish nationality or first generation EU naturalised population with Turkish roots, with $>0.5$ per cent indicating large Turkish population and $<0.5$ per cent indicating small Turkish population, sources: EUROSTAT, ZfT (Center for Turkey Studies, Essen, Germany)

11 Related to the country's rank in Turkey's foreign trade (imports and exports) balance, 'high' = Top 5; 'middle'= 6-20; 'low' = below 20; source: DIE (Turkish Statistical Office).

12 Expressed by the rank of the country in the number of Tourists visiting Turkey; 'high'=Top 5; 'middle'=6-20; 'low'= below 20; source: DIE.

13 Austria and France have both announced to ask their public after a successful diplomatic/political negotiation between Turkey and the EU institutions for the final decision on Turkey's EU membership. Some other countries are expected to apply similar referenda measures.

14 Support for EU accession expressed in polls fell from 75 per cent in December 2004 to 60 per cent in October 2005 and arrived at 55 per cent in March 2006 (Burke, 2005: 1; Zaman, 2006). See also Pusch, 2004.

\section{References}

Anholt, S. (2002) 'Foreword (to special issue on nation brands)', The Journal of Brand Management, Vol. 9, No. 4-5, pp. 229-239.

Anholt, S. (2005) 'Saving Brand Turkey. Keynote Speech at Marka 2005 (December 1-2)', Istanbul, unpublished.

Anholt, S. and GMI (2005a) 'Nation Brands Index. How the world sees the world'. http://www.gmi-mr.com/gmipoll/ press_room_wppk_pr.phtml (download on 06/10/2005).

Anholt, S. and GMI (2005b) 'How the world sees the world. The Anholt-GMI Nation Brands Index. Third Quarter 2005'. www.gmi-mr.com (download on 10/27/2005).

Anholt, S. and Hildreth, J. (2005) 'Let freedom and cash registers ring: America as a brand', Place Branding, Vol. 1, No. 2, pp. 164-172.

Baloğlu, S. and McCleary, K.W. (1999) 'US international pleasure travelers' images of four Mediterranean destinations. A comparison of visitors and nonvisitors', Journal of Travel Research, Vol. 38, pp. 144-152.

Briefing (2005) 'The row over declarations marks a new phase in Turkey-EU ties', Briefing (1561), Vol. September 5, pp. $3-5$.

Burke, J. (2005) 'A proud Turkey hesitates at the EU crossroads'. www.observer.co.uk (download on 10/6/2005).

Coffey, A. and Atkinson, P. (1996) 'Making Sense of Qualitative Data. Complimentary Research Strategies', Sage: Thousand Oaks, CA.

Dombey, D. (2005) 'Time to talk: but EU voters are uneasy as Turkey begins its quest for membership', Financial Times, (09/28/2005), Vol. 8.

European Commission (2006) 'Eurobarometer 64. Public opinion in the European Union'. http://europa.eu.int/comm/ public_opinion/index_en.htm (download on 3/11/2006).

Fesenmaier, D. and MacKay, K. (1996) 'Deconstructing destination image construction', Revue de Tourisme, Vol. 2, pp. 37-43.

Ger, G. (1991) 'Country image:Perceptions, attitudes and associations, and their relationship to context', in Proceedings of 3rd International Conference on Marketing and Development, International Society of Marketing and Development, New Delhi.

German Marshall Funds of the United States. (ed) (2005) 'Transatlantic trends - Topline data 2005'. www. transatlantictrends.org (download on 08/09/2005).

Giannakopoulos, A. and Maras, K., (eds) (2005) 'Die TuerkeiDebatte in Europa. Ein Vergleich', VS Verlag fuer Sozialwissenschaften: Wiesbaden, Germany.

Hagelueken, A. (2004) 'Groß, arm, muslimisch.' Der TuerkeiBeitritt wird teuer', Sueddeutsche Zeitung,Vol. 294, December 18-19, p. 2.

Independent Commission on Turkey (2004) 'Turkey in Europe: "More than a promise?", The British Council Brussels: Brussels.

Jaffe, E. D. and Nebenzahl, I. D. (2001) National Image and Competitive Advantage. The Theory and Practice of Country-of-Origin Effect, Copenhagen Business School, Copenhagen, Denmark.

Jaworski, S. P. and Fosher, D. (2003) 'National brand identity \& its effect on corporate brands: The nation brand effect (NBE)', The Multinational Business Review, Vol. 11, No. 2, pp. 99-110.

Kalaycioğlu, E. (2005) 'Turkey will resist reactions during negotiations with the EU. Interview with Prof. Ersin Kalaycioğlu'. www.tdn.com.tr (download on 10/20/2005). 
Kyriacou, S. and Cromwell, T. (2005a) 'The concepts and benefits of nation branding'. www.eastwestcoms.com (download on 01/06/2005).

Kyriacou, S. and Cromwell, T. (2005b) 'Corporate strategies for a nation's success'. www.eastwestcoms.com (download on 01/06/2005).

Martin, I. M. and Eroğlu, S. (1993) 'Measuring a multidimensional construct: Country image', Journal of Business Research, Vol. 28, pp. 191-210.

Olins, W. (2002) 'Branding the nation - The historical context', Opinion piece. Brand Management, Vol. 9, No. 4-5, pp. 241-248.

Omura, G. S. and Talarzyk, W. W. (1985) 'Shaping public opinion: Personal sources of information on a major political issue', in Newman, Bruce I. and Sheth, Jagdish N (eds) 'Political Marketing: Readings and annotated bibliography', American Marketing Association: Chicago, IL, pp. 95-100.

Pantzalis, J. and Rodrigues, C. A. (2005) 'Country names as brands. Symbolic meaning and capital flows'. www.sba. muohio.edu/abas/1999/pantzajo.pdf (download on 01/26/2005).
Papadopoulos, N. and Heslop, L. (2002) 'Country equity and country branding: Problems and prospects', The Journal of Brand Management, Vol. 9, No. 4-5, pp. 294-314.

Passow, T., Rolf, F. and Grahlow, H. (2005) 'Country reputation - From measurement to management: The case of Liechtenstein', Corporate Reputation Review, Vol. 7, No. 4, pp. 309-326.

Pusch, B. (2004) 'EU-Wahrnehmungen in der Tuerkei Ergebnisse der Meinungsforschung', Zeitschrift fuer Tuerkeistudien (ZfTS)/Journal for Studies on Turkey, Vol. 17, No. 1+2, pp. 113-131.

Vaknin, S. (2005) 'Nation branding and place marketing'. www. diplomatictraffic.com/nation_branding.asp (download on 11/09/2005).

Wallendorf, M. and Belk, R. (1989) 'Assessing trustworthiness in naturalistic consumer research', in Hirschman, Elisabeth C. (ed)' Interpretive Consumer Research', ACR: Provo, UT, pp. $69-84$.

Wang, J. (2006) 'Localising public diplomacy: The role of subnational actors in nation branding', Place Branding, Vol. 2, No. 1 , pp. $32-42$.

Zaman, A. (2006) 'Public support for EU membership falls'. www.zaman.com (downloaded on 20/3/2006). 